\title{
Peat Bogs, Sperm, and Family Values: Teaching Naturalism Charitably
}

\author{
Marc Champagne ${ }^{1}$
}

Published online: 16 February 2016

(C) Springer Science+Business Media New York 2016

\begin{abstract}
Introductory courses dealing with sex, gender and sexuality often assign excerpts from Thomas Aquinas as an exemplar of the naturalist view. Given that most novice students tend to side against such naturalism uncritically, they need to be exposed to a more charitable account of the biological considerations motivating a stance like Aquinas.' With that in mind, this article presents accessible arguments aimed at restoring deliberative balance in the classroom.
\end{abstract}

Keywords Sex $\cdot$ Teleology $\cdot$ Biological function $\cdot$ Naturalism $\cdot$ Conventionalism . Pedagogy

1. Introductory college and university courses dealing with sex, gender and sexuality often structure their discussion as a back-and-forth between two basic explanatory models that center on nature and culture, respectively. As a prominent figure of the naturalist camp, the philosopher and Christian theologian Thomas Aquinas gets included in many syllabi. Yet, excerpts from Aquinas-one of the most prolific and historically significant thinkers of the Western canon-often serve as a sort of "piñata": his texts are brought out only so that students can take turns bashing them.

Aquinas argues that (1) only heterosexual couples should have sex, and that (2) they should do so only once married and (3) only for the sake of procreation. This is the controversial stance that lands him in anthologies and course kits. As a rule,

Marc Champagne

marcchampagne@trentu.ca;

https://www.trentu.ca/philosophy/faculty_champagne.php

1 Department of Philosophy, Trent University, 1600 West Bank Drive, Peterborough,

ON K9J 7B8, Canada 
students tend to side against his position from the get-go. To their novice eyes, permissive social constructivism seems like a much safer position. Alas, such uncritical consensus is not conducive to genuine inquiry. Of course, if a convergence of beliefs takes place after genuine deliberation, that is another matter. But, to see a class agreeing so uniformly, so early in the game, should be pedagogically and philosophically alarming-especially when dealing with topics as complex as sex, gender and sexuality.

Like all people, students have prior opinions. However, it is doubtful that, early into an undergraduate course, anyone has any real defendable reason(s) for why they think what they think. In an academic context driven by evidence and argument, gut reactions should mean next to nothing. Until and unless we can get clear on the reasons given by Aquinas, the fact that he champions conservative values should be unimportant. Good scholarship demands that we give a thinker a fair hearing before evaluating her ideas (one does not have to pay tuition to adopt this laudable mindset).

Interpreting a thinker charitability is more than abiding by textual fidelity; it is presenting the relevant ideas so that they come across as persuasive. In the case of Aquinas, this is rarely done. There is a vast primary and secondary literature on him, but what is lacking is a jargon-free presentation that students can relate to. Only once we have a firm handle on the core motivations of his stance should we beef up that skeletal argumentative structure with details, otherwise the essential point will get lost. So, in the sections that follow, I am going to try to defend Aquinas' naturalist view of sexuality, as persuasively as I can.

For a host of psychological reasons, conveying ideas persuasively requires being persuaded by them, if only provisionally. So, to stress this provisional character, I want to make it clear that what I am setting out to defend is not a Christian conservative mindset, but rather genuine inquiry. Those gripped by a militant sense of conviction can sometimes see enemies even among allies, so if one finds oneself chomping at the bit with objections, then one should direct those objections at Aquinas, not me. Indeed, in another context, I might be the one voicing criticisms. But, regardless of their source, such criticisms will mean little if they thrash the good and bad parts of a theory indiscriminately. Biological naturalism has a lot going for it, so I want to promote a more balanced appraisal.

2. Aquinas wants to defend the sanctity of heterosexual marriage using natural evidence. At first glance, his approach seems misplaced, since marriage is clearly a social act: usually, there is an exchange of rings, a third party witnessing the vows, a paper trail that records the event, and so on. All of this looks like a contract, bound only by mutual agreement(s). Yet, Aquinas wants to argue that social mores pertaining to relationships can, do, and should have an underlying natural basis that is not merely conventional. Logically, if one is unconvinced that such mores "can" have a natural basis, one will not endorse the stronger claims that they "do" and "should" have such a basis. Even so, let me try to motivate the idea that some cultural institutions (like marriage) can have an underlying natural basis.

Aquinas' arguments rely heavily on the notion of natural function. Aquinas holds that the natural end of sperm-what sperm is for-is procreation. He uses this goal- 
directedness as a normative standard, such that "it is good for everything to gain its end, and evil for it to be diverted from its due end" (Aquinas 2009, p. 65). In this way, Aquinas links theology and teleology. Practically speaking, he thinks that "every emission of the semen is contrary to the good of man, which takes place in a way whereby generation is impossible; and if this is done on purpose, it must be a sin" (ibid.). Even with this superficial rendering, one can sense that some of the links in Aquinas' arguments are tenuous. Even so, those arguments appeal to biological considerations that, when properly understood, cannot be easily dismissed.

Aquinas makes much of the fact that, without sperm, a given species would not survive. So, even "though the semen is superfluous for the preservation of the individual, yet it is necessary to him for the propagation of the species" (Aquinas 2009 , p. 65). Biology obviously recognizes the pivotal role of sperm as a conveyor of genetic baggage, along with the female egg. Many contemporary biologists would add that this evolutionary function to create offspring is probably what led the sex act to become pleasurable. After all, animals are more likely to engage in something if it is pleasurable than if it is not. This plausible evolutionary reconstruction would explain why many mammals have been observed engaging in homosexual behavior and/or masturbation. Surely these last pieces of animal behaviour are part of naturalism too. Yet, Aquinas sees the same data differently. For him, helping oneself to the hedonistic bonus of sex without fulfilling the main function/purpose of that activity is in some sense "wrong."

Aquinas argues that, owing to their rational faculty, humans stand apart from other animals in an important way, such that the inference from what many mammals do to what we should do does not go through as smoothly. The experience of pleasure during sex remains undeniable. "It is in fact quite clear that Aquinas thought it entirely reasonable to be interested in and motivated by the prospect of enjoying the pleasures of marital sexual intercourse" (Finnis 1997, p. 102). But, Aquinas deemed it "wrong to make sexual pleasure one's sole motive in or for intercourse" (ibid., p. 103). On this view, the permissibility of hedonism is constrained by the satisfaction of natural functions. Only when the latter is met can the former be indulged in.

This idea may meet with frowns on most urban university campuses, but the fact is that, Christian or not, a large part of the world actually agrees with Aquinas' conservative prescriptions. Moreover, the stance promoted by Aquinas "is alive and well today among some philosophers of sex, even if the details do not precisely match Aquinas's original version" (Soble 2002, p. xxxiv). So, those who want to sweep this broad view under the rug will need a very big rug. Truth or falsity cannot be settled by a vote. Still, it is always nice to know why those around us believe the things they do, especially in classrooms with diverse cohorts.

Understanding Aquinas, however, requires a shift in vantage. As a systembuilder, Aquinas argues from premises which are in turn conclusions of prior arguments. Hence, whenever he says something about "what one should do" in ethics, it is because of commitments on "what one can know" in epistemology. Likewise, if he says something about "what one can know" in epistemology, it is because of commitments on "what there is" in metaphysics. In this standard 
subsumption relation, ethical inquiry subsumes two inquiries, and Aquinas wants to go all the way down. This ambitious approach led him to write vast "sums" (Summa in Latin) meant to capture all of human knowledge, without remainder. As a result, the common academic practice of studying an excerpt in isolation is simply inappropriate when studying the ideas of Aquinas. He was aiming for synthesis, not sound-bites.

Because attempts to answer ethical questions depend on more basic answers in epistemology and metaphysics, Aquinas drew on (Aristotelian) science to defend his view of sex and marriage. In light of current frictions between science and religion over topics like abortion and creationism, this appeal to science may seem surprising. Yet, science and religion were not always considered enemies. Indeed, Aquinas believed that, since God would never deceive humankind, whatever results humans achieve by way of scientific inquiry should in principle converge with the truths gleaned by revelation. Working from this conviction, he always made sure that the end-points of his arguments always agreed with Church dogmas.

Thus, when looking at Aquinas' work, we normally find two paths converging on common claims. One path is natural and secular, while the other path is supernatural and religious. Because of this, Aquinas enjoys a sort of double-citizenship in the intellectual world. Some read him to elucidate their understanding of Catholic beliefs, whereas others read him for the independent merit of his arguments. To portray him only as a religious thinker would be wrong. It would like inferring that, because a great cook was also a great athlete, that person was never a great cook. Now, I am a professional philosopher, so I reject revelation as a source of knowledge. Still, to the extent that the arguments in question have merit, I see no reason why I cannot follow Aquinas down his secular route. We know in advance what conclusions he is going to reach, but it can be instructive to reconstruct his reasoning.

3. As mentioned, Aquinas draws on Aristotelian science to justify his views. Aristotelian science was a successful predictive and explanatory paradigm that served Western thinkers for close to two millennia. Aristotle was a natural philosopher concerned with determining the essential and accidental properties of things, so in many respects his inquiry does not fit with what we would today consider science. Still, when it comes to biology, the Aristotelian approach shares two traits with contemporary science: it relies on observation and it generalizes particular observations into theories that have a wider scope.

To illustrate this interplay between observation and generalization, we can consider a straightforward example. Suppose that you are a scientist studying peat bogs. You get a research grant, put on your boots, go in the field, and take various measurements. Whatever you glean about peat bogs is not invented; rather, it is discovered. This is observation. Eventually, after observing quite a large number of peat bogs that have, say, rounded edges, you conclude that "Peat bogs have rounded edges." The statement about peat bogs having rounded edges does not apply to just one peat bog; rather, it is intended to range over all peat bogs. This is generalization.

Now, suppose that one day you encounter a peat bog in Norway that has a jagged edge. This counter-example can also be observed, so should it prompt you to abandon 
your previous hard-earned generalization about rounded edges? Not likely. Some schools (e.g., Popper 2002) recommend total falsification of a scientific theory at the first sign of a counter-example, but in most cases this recommendation would bring cognition to a halt (recent advances in machine learning have effectively falsified the Popperian claim that generalization is a myth; see Gillies 2009, pp. 105-107). So, instead of tossing away all the observations made in notepads over the years, a more parsimonious response would be to gloss the jagged-edged bog in Norway as a statistical anomaly which can be recorded but safely overlooked. What matters is that, in $99 \%$ of the cases, the edges are round. Anyone who would fail to pay attention to this bulk feature would fail to understand peat bogs.

Now, let us re-apply this generic scientific methodology of observation and generalization to a case related to sex, namely sperm. Sperm is found among males of non-human animals. Some of those non-human animals may stay committed sexual partners, but they certainly do not get married. So, to keep the topic less controversial, assume that everything I am about to say pertains to, say, squirrel sperm.

Science, as we saw, is based on observation, and in order for particular observations to yield usable knowledge, one has to generalize those observations in a way that overlooks minor aberrations. Indeed, one of the first things one learns in experimental methodology classes is how to round out numerical results. What does this mean for sperm?

Let us rely on observation to determine what actually goes on when sperm enters a vagina. Lots and lots of sperm swim about. Chemicals emitted by this group of sperm are needed to alter the egg's wall and allow a sperm to enter, but only one sperm actually enters the egg. This means that $99 \%$ hit the walls of the vagina or uterus, and less than $1 \%$ hits the egg (were we to count all the sperm that ends up in tissues, that percentage would be very low). Like the single Norwegian peat bog that had escaped the feature of roundedness, should we therefore round-out the statistics and conclude that "Spermatozoa are cells released in male semen that hit vaginal and uterine walls"?

If we did this-if we dismissed the one sperm that reaches the ovum-we would fail to properly understand the nature of sperm. Unlike the peat bogs with jagged edges, here it is the majority of $99 \%$ that needs to be overlooked.

This raises an important question: What justifies overlooking such an abundance of data in favor of a single, statistically irrelevant, event? Drawing on Aristotelian science, Aquinas would answer that what makes the single spermatozoon outweigh all the rest is the function that it serves (and that function, he would argue, is not to moisten tissues).

Humans are not squirrels. So, using cultural channels like shared language, can we just decide that "hitting vaginal and uterine walls" is the proper function of sperm? How much can our conventional agreement about this or that alter how things in fact are? Thomas Aquinas proceeds from the assumption that biological functions exist, and that what these functions are for-i.e., their teleology or goaldirectedness - is not up to us. Of course, Aquinas would acknowledge that bodily acts besides male/female procreative coupling are possible-masturbation, for instance, does not contravene the laws of his (or any other) physics. However, he argues that, while possible, such acts nevertheless misapply a natural function. 
In the course of evolution, some features that were initially selected by a set of environmental pressures can end up being put to a different use (Gould and Vrba 1982). Sex for pleasure would thus co-opt the role of organs that owe their existence to the promotion of fitness (this is certainly more true of the penis than the clitoris, a region of the female anatomy about which Aquinas has very little to say; see Gudorf 1994, p. 65). Humans, however, do not deviate from a natural function in the same passive manner that a river deviates from its established course. Rather, because humans have free will, they can assess their "deviancy" in a normative key. This, at any rate, is what Aquinas contends.

In saying this, Aquinas is essentially trying to vindicate religious dogma, in a way so successful that he was made the official philosopher of the Catholic Church. Even so, the fact that a major religion enlists his writings does not rob Aquinas' main argument of its plausibility: When it comes to biological subjects, there is a mind-independent rationale that allows us to distinguish some functions as primary (or "natural") and others as derived (or "un-natural"). This is the key idea that students must understand if they are to have a genuine appreciation of what drives Aquinas' claims about sex, gender, and sexuality. Attending only to his rejection of libertine ways without exploring his biological account would merely scratch the surface.

4. Rejecting or endorsing the naturalness of biological functions may seem like a purely theoretical matter, but it has a host of practical consequences. For instance, as part of his discussion of marriage, Aquinas levels arguments against what we would nowadays call "deadbeat dads," giving positive reasons for why educating one's child(ren) is an important long-term responsibility. In Aquinas' words, "the fitness of human life requires man to stand by woman after the sexual act is done, and not to go off at once and form connections with any one he meets [...]" (2009, p. 65). So, if one jettisons Thomistic naturalism on account of marriage being just an accepted lifestyle choice, then one also jettisons a cluster of powerful arguments calling for parental responsibility.

Once an umbilical cord has been cut and a child becomes physically separate from its mother, why should sustained parental care matter? Unqualified adherence to social constructivism would seem to imply that parenting is an optional endeavor, even if opted for often. If this is right, then abandoning a baby on a street corner is a bit like farting in public: it is something which happens to go against shared social norms, but which is no more or less intrinsically wrong outside of those norms. This comparison between public farting and parenting will, I hope, engender a recoil-a strong sense that there is clearly something that sets them apart. If so, then just what is the difference? Is giving up a child just an unpopular practice met with various social penalties, or is there some natural fact that commits a parent to supplying nourishment and education over the long haul?

Typically, beginning students who are asked this question try to have it both ways: they hold that it is okay to forgo having a child, but not okay to forgo caring for a child once you have it. Or, they hold that, minimally, someone somewhere should care for the child, and that this holds for all cultures. Why is this? Switching theories on an ad hoc basis is facile, but what principled reason underpins this 
student conviction that child abandonment is really wrong and not just unfashionable? Appealing to shared emotions only slides this question one notch away, because those emotions surely have a source, and we can rightfully ask whether that source is nature or nurture or both (in which case careful disambiguation would be required).

Now, if it is plausible to think that parent-child unions are underwritten by considerations that go beyond mere social convention, why wouldn't it be likewise plausible to think that parent-parent unions also enjoy a natural basis? In other words, if a newborn comes into this world expecting to be cared for by one or more adult(s), why is it extravagant to suggest that a newborn comes into this world expecting to be cared for by the two adults who actually made it? Social constructivists can of course say that strong normative groundings owe their strength to the social agreement(s) about them. But, there are other accounts besides this, and students should competently be made aware of those alternatives.

There are undoubtedly flaws in the arguments supporting naturalist views, but Aquinas at least gives us reasons to evaluate. Whatever else he may be, he is certainly not a moving target. Skipping a charitable study of his reasons just to feel safe in pre-existing beliefs would be a missed opportunity. One is of course free to champion same-sex relationships and/or find no problem in non-procreational sex, but doing so burdens one with explaining why vast segments of the world population simply do not agree. If nothing else, the conservative opinions of one's fellow humans will appear less mysterious when one attends to the more prominent justifications from which those opinions descend.

5. By highlighting the crucial difference between predominantly-rounded-peatbogs and predominantly-unsuccessful-sperm, I have tried to motivate the view that some functions might be natural. If goal-directedness does not enter the picture, then statistical rounding-out obliges us to say that "sperm do not work," when in fact our very life shows that, clearly, they do. One might object that these arguments rest on an Aristotelian notion of teleology that is antiquated and disproven. But, interestingly, teleology has never disappeared from (and is arguably making a comeback in) current debates (see Ariew et al. 2002). In any event, the fact remains that many lay people-notably Catholics-routinely appeal to goal-directedness when discussing their views on sex. So, even without the natural story, this widespread cultural trend warrants our taking a closer look.

Treating naturalist accounts of sexuality with a minimum of intellectual respect still leaves many questions unanswered. For instance, does accepting the reality of biological functions necessarily entail buying into specific ethical/political doctrines? When the sperm hits the egg, it feels nothing, but when a man ejaculates, he feels something. Does that matter? If so, why? Is there a worthwhile distinction to be made between an "organ" and an "organism"? If so, what are the differences and similarities? Can we run the same goal-directed account on an organ like the clitoris? Can one grant the claim that some functions are natural while holding that non-marital relationships are okay too? After all, if being a great athlete or theologian does not preclude one from also being a great cook or philosopher, why 
should having casual sex with multiple partners preclude one from also being a lifelong sexual partner to a single person?

Pursuing some or all of these questions seems more promising than simply restating what Aquinas believed in a disapproving tone. Consider the inference that "If the penis entering the vagina is the paradigmatic natural act, then any other combination of anatomical connections will be unnatural and hence immoral" (Soble 2002, pp. xxx-xxxi). It is one thing to grant the antecedent of this if-then conditional, but a lot of missing links have to be inserted for the supplementary ethical conclusion following the "hence" to actually follow. Classroom discussion can, I think, be profitably directed to those missing links. However, disapproval without justification is no better, rationally speaking, than stamping one's foot.

Of course, it sometimes happens that, at the close of a finite inquiry, we end up right where we started, belief-wise. However, educators who say that they want to "make a difference" must be open to the possibility that students exposed to new ideas might emerge with beliefs genuinely different from their professors (and/or their former selves). If students walk away from a class remembering only that Aquinas was a dead religious nutter who believed in straight vanilla sex (to use their argot), or walk away only with a newfound ability to dress up that undefended assessment in fancier-sounding jargon, then something has gone seriously wrong. True, Aquinas believed all that, but he also said a lot more.

Students do not need to attend college or university to have opinions about sexuality; they can already have those opinions for free at the local coffee shop. Intellectual work consists in subjecting those opinions to critical scrutiny. However, such scrutiny will amount to little unless it is informed by charitable portrayals. Of course, if the tenets of Thomism must be endorsed as a whole, then I do not endorse Thomism (I suspect few academics would). To reiterate my disclaimer, what I defend is not Christian conservativism, but rather genuine inquiry. Yet, one does not have to consider Aquinas a Saint to realize that what he has to say is sensible enough to spare his texts from serving as a classroom piñata. If this essay can help to make that practice less common, then I will be satisfied.

\section{References}

Aquinas, T. (2009). Of the reason for which simple fornication is a sin by divine law. In R. B. Baker \& K. J. Wininger (Eds.), Philosophy and sex: Adultery, monogamy, feminism, rape, same-sex marriage, abortion, promiscuity, perversion (pp. 64-70). Amherst, NY: Prometheus Books.

Ariew, A., Cummins, R., \& Perlman, M. (Eds.). (2002). Functions: New essays in the philosophy of psychology and biology. Oxford: Oxford University Press.

Finnis, J. M. (1997). The good of marriage and the morality of sexual relations: Some philosophical and historical observations. American Journal of Jurisprudence, 42(1), 97-134.

Gillies, D. (2009). Problem-solving and the problem of induction. In Z. Parusniková \& R. S. Cohen (Eds.), Rethinking popper (pp. 103-115). Dordrecht: Springer.

Gould, S. J., \& Vrba, E. S. (1982). Exaptation-A missing term in the science of form. Paleobiology, $8(1), 4-15$.

Gudorf, C. E. (1994). Body, sex, and pleasure: Reconstructing christian sexual ethics. Cleveland, OH: Pilgrim Press. 
Popper, K. (2002). Conjectures and refutations: The growth of scientific knowledge. London and New York: Routledge and Kegan Paul.

Soble, A. (Ed.). (2002). Philosophy of sex and love: Contemporary readings (4th ed.). Lanham, MD: Rowman and Littlefield. 